\section{WORKABILITY AND RHEOLOGICAL PROPERTIES OF EVA-MODIFIED BITUMEN COMPARED WITH PG 76 BINDER}

\author{
Ebenezer Akin Oluwasolaa, Mohd Rosli Haininb*, Mohd Khairul \\ Idhamb, Modupe Abayomic
}

aDepartment of Civil Engineering Technology, Federal Polytechnic Ede, Nigeria

bDepartment of Geotechnics and Transportation, Faculty of Civil Engineering, Universiti Teknologi Malaysia, 81310 UTM Johor Bahru, Johor, Malaysia

cDepartment of Civil Engineering, Landmark University, Omu Aran, Nigeria
Article history

Received

25 October 2017

Received in revised form

12 February 2018

Accepted

20 February 2018

Published online

3 June 2018

*Corresponding author mrosli@utm.my

\section{Graphical abstract}

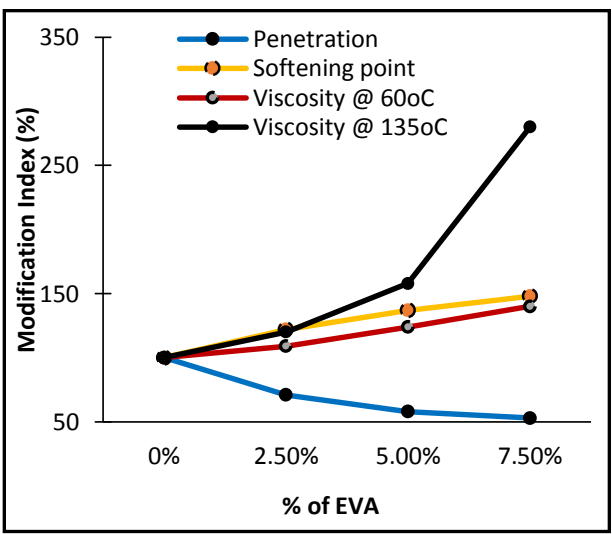

\section{Abstract}

The failures of the flexible pavements are not only caused by harsh climatic conditions prevailing in most of the tropical countries but also due to increase in traffic. The ethylene vinyl acetate (EVA) modification of the bitumen can strengthen the properties of binders and also improve the quality of bitumen used for pavements construction. This paper reports the changes in physical and rheological properties of unaged 80-100 grade bitumen modified with different percentages of EVA and compared with the properties of PG 76 binder. The penetration, softening point and viscosity properties were studied. The rheological properties were measured using dynamic shear rheometer and the test was performed at temperatures ranging from 46 to $76{ }^{\circ} \mathrm{C}$ at intervals of $6{ }^{\circ} \mathrm{C}$. It was noted that, after modification, the properties of binders had improved. The results show that 5\% EVA content by weight in modified binder is adequate in terms of physical and rheological properties studied. In addition, the properties of 5\% EVA modified $80-100$ grade bitumen are similar to PG 76 binder.

Keywords: Ethyl Vinyl Acetate (EVA), workability properties, rheological properties, modification, bitumen, modification index 


\begin{abstract}
Abstrak
Kegagalan turapan lentur bukan sahaja disebabkan keadaan iklim yang melampau yang lazimnya berlaku di negara-negara tropika tetapi juga disebabkan peningkatan beban trafik. Pengubahsuaian bitumen dengan ethylene vinyl acetate (EVA) boleh menguatkan ciri-ciri pengikat secara tidak langsung meningkatkan kualiti bitumen yang digunakan untuk pembinaan turapan. Kajian ini melaporkan perubahan ciri-ciri fizikal dan reologi 'unaged' bitumen bergred 80-100 diubahsuai dengan peratusan EVA yang berbezabeza dan dibandingkan dengan ciri-ciri pengikat bitumen PG 76. Ciri-ciri penusukan, titik lembut, dan kelikatan telah dikaji. Ciri-ciri reologi diukur menggunakan 'dynamic shear rheometer' dan ujian dijalankan antara suhu 46 hingga $76{ }^{\circ} \mathrm{C}$ pada sela $6{ }^{\circ} \mathrm{C}$. Selepas pengubahsuaian, didapati ciri-ciri pengikat bertambah baik. Keputusan menunjukkan $5 \%$ kandungan EVA daripada berat pengikat terubahsuai mencukupi dalam kajian ciri-ciri fizikal dan reologi. Sebagai tambahan, ciri-ciri 5\% EVA terubahsuai dengan bitumen bergred 80-100 adalah sama dengan pengikat PG 76.

Kata kunci: Ethyl Vinyl Acetate (EVA), ciri-ciri kebolehkerjaan, ciri-ciri reologi, pengubahsuaian, bitumen, index pengubahsuaian
\end{abstract}

(C) 2018 Penerbit UTM Press. All rights reserved

\subsection{INTRODUCTION}

Bitumen can be classified as a thermoplastic material and is commonly used as a binder material in flexible highway and airport pavement construction [1]. However, bitumen should be flexible enough at high temperatures to resist unexpected stress without cracking and most also withstand permanent deformation [2-5]. In view of this, at high and low service temperatures, bitumen most withstand stresses caused by traffic loads. Thus, certain special bitumen modifications that can enhance the resistance to permanent deformation and fatigue life of paving mixes may be needed where traffic is heavy [6-10]. This can be achieved by modifying the readily available bitumen with certain additives, which include polyethylene, polypropylene, latex, styrenebutadiene-styrene, ethylene vinyl acetate, styrene butadiene rubber and sasobit. The main objective of bitumen modification is to produce new binders with improved mechanical and rheological properties. The improvement in the modified bitumen can be attributed to the chemical change resulting from the interaction between the molecular structure of the added modifier and binder. Many research works have been carried out on the properties of the modified binders, assessing their advantages over the conventional bitumen.

Panda and Mazumdar [11, 12] stated that the viscosity and softening point temperature of the EVA modified binders increased while their ductility, penetration, and specific gravity decreased. There was also an improvement in temperature susceptibility of the modified binder. The use of EVA increased its tensile strength, air voids, and Marshall stability up to $14 \mathrm{kN}$ and decreased its unit weight and flow.

Airey [13] stated that the EVA polymer improved the rheological properties of bitumen. Conventional penetration, ductility, softening point, and high temperature viscosity tests showed that the EVA polymer modified bitumen had improved temperature susceptibility and hardness. Gonzalez et al. [14] reported that with EVA the viscoelastic properties of 60-70 grade bitumen were improved. Also, the risk of rutting at high temperatures and cracking at low temperatures were both reduced. A general evaluation of stability tests showed that the performance of this bitumen as a binder for road pavement was greatly improved when $1 \%$ of EVA was added.

Morales and Partal [15] established that the addition of recycled EVA improved the viscous properties of bitumen at high temperatures. The increase in EVA concentration affects the microstructural changes, which greatly influence the flow behaviour of the binder. Bulatovic et al. [1] reported that the polymer content improved the physical and rheological properties and morphology of the polymer modified bitumen. Also the EVA polymer improved the rheological properties of road bitumen. Kumar et al. [16] studied the properties of EVA modified bitumen before and after aging. He reported that the physical properties of bitumen such as its softening point and penetration were improved with the addition of EVA. Also the effect of aging on EVA modified binders was within the permissible limits. The purpose of doing the present research work is to compare the physical and rheological behavior of EVA modified bitumen with PG 76. 


\subsection{METHODOLOGY}

\subsection{Materials and Preparation of Modified Bitumen}

In this study, two grades of bitumen binders were used: pen 80-100 and PG 76. Also, pen 80-100 binders were modified with various percentages of EVA (0-7.5\%) with an increase of $2.5 \%$. For the preparation of EVA modified bitumen, bitumen was heated to a temperature of $170{ }^{\circ} \mathrm{C}$, the different EVA polymer contents by mass (2.5 to $7.5 \%$ ) were added to the bitumen. The temperature was maintained at $175^{\circ} \mathrm{C}$ $\pm 1^{\circ} \mathrm{C}$ and blending was done with high shear mixer for a period of one hour.

\subsection{Testing Methods}

\subsubsection{Penetration Test}

The penetration of a bituminous substance may be defined as the distance (in hundredths of a centimeter) to which a standard needle penetrates the material under known conditions of time, loading, and temperature. This test is used for evaluating the consistency of asphalt materials before and after heating. The test was conducted in accordance with the procedure specified in ASTM D 5M [17] for all the binders used in the study.

\subsubsection{Softening Point Test}

The ring-and-ball softening point test is used to measure the susceptibility of blown asphalt to temperature changes by determining the temperature at which the material will be adequately softened to allow a standard ball to sink through it. The softening point of the bitumen is the temperature at which the binder can no longer support a standard steel ball with a weight of $3.5 \mathrm{~g}$. The test was performed in accordance to ASTM D 36 [18].

\subsubsection{Viscosity Test}

Viscosity is the resistance of a fluid to flow. In this study, the test was performed using a Brookfield Thermosel viscometer. Viscosity is measured using the standard test procedure outlined in ASTM D4402 [19]. The test involves measuring the time required for a fixed volume of liquid to be drawn through one of the several specially designed capillary tubes by means of a vacuum. The absolute viscosity in poises is determined by multiplying the flow time in seconds via the viscometer calibration factor.

\subsubsection{Dynamic Shear Rheometer Test}

The dynamic shear rheometer apparatus is used to examine resistance to high temperature rutting (permanent deformation), intermediate pavement temperature fatigue cracking and low pavement temperature thermal cracking. The test was performed using dynamic shear rheometer (DSR) apparatus to evaluate fatigue and rutting resistance. The test is mainly software controlled.

The DSR is used to characterise the elastic and viscous behaviour of bitumen binders at high and intermediate service temperatures [20, 21]. The DSR measures the complex shear modulus, $G^{*}$, and phase angle, $\delta$, of bitumen binders at the desired temperature and frequency of loading. The test was performed in accordance with ASTM D 7175 [22]. The DSR apparatus used in this research was the HAAKE Rheostress 1.

The principle of operation of a DSR is shown in Figure 1. The bitumen binder sample was sandwiched between a fixed plate and an oscillating plate. When torque was applied to the oscillating plate, the plate starts from point $A$ and moves to point $B$. From point $B$, the plate moves back and goes to point $C$, passing point $A$. From point $C$ it returns back to point $A$. This movement composes of one cycle of oscillation. If two oscillation cycles occur in one second, the frequency of oscillation would be two cycles per second or $2 \mathrm{~Hz}$. The frequency of oscillation can also be expressed as the radians traversed by the oscillating plate in one second. In this study, the DSR was conducted at a frequency of 10 radians per seconds, which is equivalent to approximately $1.59 \mathrm{~Hz}$.

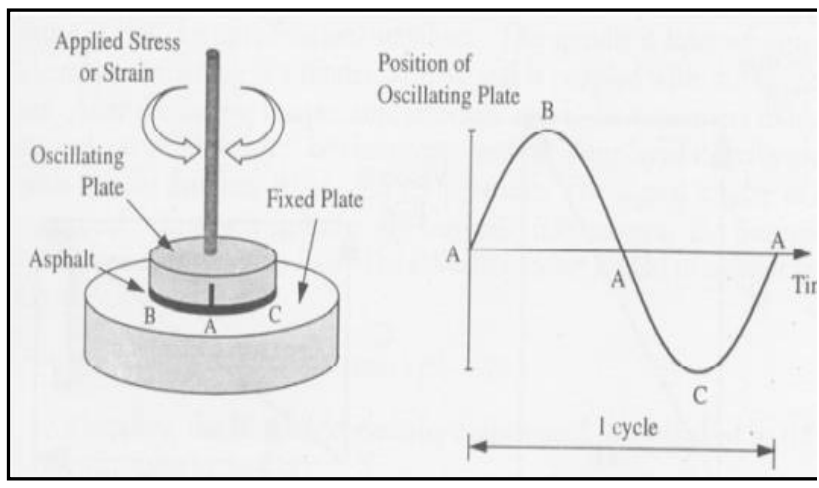

Figure 1 The principle of Dynamic Shear Rheometer [22]

The thickness of the bitumen binder sample sandwiched between the fixed plate and the oscillating spindle depends on the test temperature. Higher test temperatures $\left(\geq 46^{\circ} \mathrm{C}\right.$ ) require a small gap of $1 \mathrm{~mm}$ while lower test temperatures in the range of 4 to $40{ }^{\circ} \mathrm{C}$ require a larger, $2 \mathrm{~mm}$ gap. Also, two spindle diameters are used i.e., large spindle $(25 \mathrm{~mm})$ for high test temperature and small spindle $(8 \mathrm{~mm})$ for low test temperatures.

After the bitumen binder sample was sandwiched between the fixed plate and the spindle, the designed test temperature has to reach within $\pm 0.1^{\circ} \mathrm{C}$ using the water bath. When the spindle was oscillated back and forth with constant stress, the resulting strain was monitored. The relationship between the applied stress and the resulting strain was used to compute the complex modulus, $G^{*}$. The complex modulus is the 
ratio of maximum shear stress ( $\mathrm{T}$ max) to maximum shear strain ( $y$ max). The time lag between the applied stress and the resulting strain is the phase angle, $\delta$. The physical property measurements of $G^{*}$ and $\delta$ for a given bitumen binder were taken three times using the DSR. The bitumen binder was tested in the DSR in its unaged condition. In this study, the initial temperature for the test was set at $46{ }^{\circ} \mathrm{C}$ and increased in steps of $6{ }^{\circ} \mathrm{C}$ until the specimen failed (conditions not met).

\subsection{RESULTS AND DISCUSSION}

\subsection{Penetration Value}

The results of penetration test for the unmodified and modified binders are shown in Table 1. As can be clearly observed in Table 1, EVA has a significant effect on the penetration of the 80-100 binder. It is noted that the penetration decreases as the modifier concentration increases. The 5\% EVA modified bitumen displays properties similar to PG 76-22 bitumen in terms of penetration. A similar result was reported by Kumar et al. [16] and Airey [13] in their studies on EVA modified bitumen.

Table 1 Penetration test result of the binder

\begin{tabular}{lc}
\hline Binder type & Mean of Penetration Values \\
\hline $80-100$ & 85 \\
$2.5 \%$ EVA $80-100$ & 60 \\
$5.0 \%$ EVA $80-100$ & 49 \\
$7.5 \%$ EVA $80-100$ & 45 \\
PG 76-22 & 48 \\
\hline
\end{tabular}

\subsection{Softening Point}

Table 2 below provides the summary of the softening point test for the binders and shows that the softening point significantly increases with an increase in modifier concentration because the bitumen also becomes increasingly viscous. The softening point of $7.5 \%$ EVA modified 80-100 bitumen increases to nearly $70{ }^{\circ} \mathrm{C}$. In a study conducted by Kumar et al. [16], it was suggested that modified bitumen with more than a 70 ${ }^{0} \mathrm{C}$ softening point value may not be appropriate for use in road construction; rather it may be utilised as roofing material instead. Thus, $7.5 \%$ EVA modified 80 100 bitumen may not be a good binder for road construction. Similar to its penetration test value, $5 \%$ EVA modified 80-100 bitumen shows characteristic similar to PG 76-22 in terms of softening point. A similar observation was made in a related research by Gonzalez et al. [14].
Table 2 Softening point test result of the binder

\begin{tabular}{lc}
\hline Binder Type & $\begin{array}{c}\text { Mean of Softening Point Values } \\
\left({ }^{\circ} \mathbf{C}\right)\end{array}$ \\
\hline $80-100$ & 46 \\
$2.5 \%$ EVA $80-100$ & 56 \\
$5.0 \%$ EVA $80-100$ & 63 \\
$7.5 \%$ EVA $80-100$ & 68 \\
PG 76-22 & 64 \\
\hline
\end{tabular}

\subsection{Viscosity}

Viscosity grading of bitumen binders is based on viscosity measurement at $60{ }^{\circ} \mathrm{C}$ and $135{ }^{\circ} \mathrm{C}$ as suggested by the Strategic Highway Research Program (SHRP) [24]. To obtain a viscosity at $60^{\circ} \mathrm{C}$, the test was initially performed at $90{ }^{\circ} \mathrm{C}$ since the spindle of the Viscometer cannot rotate effectively when used at $60{ }^{\circ} \mathrm{C}$. The viscosity at $60^{\circ} \mathrm{C}$ was later obtained by using a linear interpolation of viscosity at temperatures of $90{ }^{\circ} \mathrm{C}$ and $135^{\circ} \mathrm{C}$. The line is linear because viscosity is the ratio between shear stress and shear rate.

According to the SHRP, the shear rate is determined as a constant variable, i.e. $6.8 / \mathrm{s}$ and remains constant for all test temperatures. The linear relationship between viscosity values was used by Rusbintardjo [25] to determine the proper mixing and compaction temperatures of the hot mix asphalt (HMA). The linear relationship between viscosity values is illustrated in Figure 2. The detailed viscosity test results are summarised in Table 3.

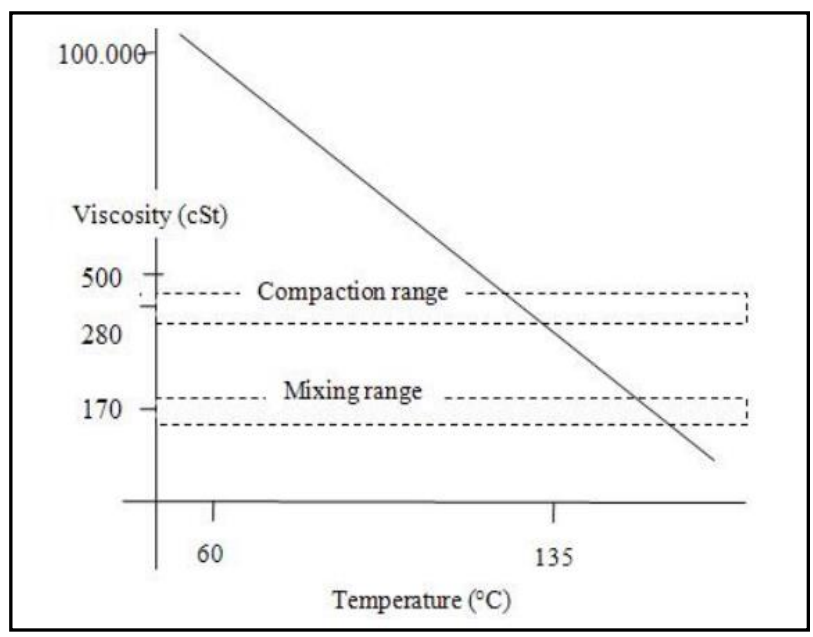

Figure 2 Temperature-Viscosity relationship [26]

As noted from Table 3, the higher the percentage of EVA added to 80-100 the more viscous it becomes. In addition to this, the increase in the value of viscosity is much more significant when $7.5 \%$ EVA is added to 80-100 bitumen. The obtained viscosity result conforms to the result of a similar study by Kumar et al. [16]. 
Table 3 Viscosity test result of the binder

\begin{tabular}{llc}
\hline \multirow{2}{*}{ Binder type } & \multicolumn{2}{c}{ Mean of viscosity (CP) } \\
\cline { 2 - 3 } & $\mathbf{6 0}{ }^{\circ} \mathbf{C}$ & $\mathbf{1 3 5}{ }^{\circ} \mathbf{C}$ \\
\hline $80-100$ & 23200 & 400 \\
$2.5 \%$ EVA 80-100 & 25400 & 480 \\
$5.0 \%$ EVA 80-100 & 28700 & 630 \\
$7.5 \%$ EVA 80-100 & 32500 & 1220 \\
PG 76 & 36200 & 1800 \\
\hline
\end{tabular}

\subsection{Rheological Properties}

The test was conducted at $46{ }^{\circ} \mathrm{C}, 52{ }^{\circ} \mathrm{C}, 58{ }^{\circ} \mathrm{C}, 64{ }^{\circ} \mathrm{C}$, $70^{\circ} \mathrm{C}$ and $76^{\circ} \mathrm{C}$ within the linear viscoelastic region of the binder so that the stress and strain relationship is only influenced by the frequency of loading and not by the magnitude of the stress and strains [27]. The detailed DSR results are graphically illustrated in Figures 3 and 4.

The parameter, shear modulus ( $\left.G^{*} / \sin \delta\right)$ measures the stiffness of the bitumen and is also used as a guide for rutting resistance in the present superpave specifications. From Figure 3, it is observed that the shear modulus of the bitumen increases with increase in the concentration of modifiers. This suggests that EVA contributes to the bitumen stiffness. In addition to this, the rate of increment is more significant at higher temperatures $\left(>52{ }^{\circ} \mathrm{C}\right)$. For instance, an addition of 5 per cent EVA with 80-100 bitumen increases the rutting resistance by more than $44 \%, 110 \%, 141 \%$, and $157 \%$ at $58{ }^{\circ} \mathrm{C}, 64{ }^{\circ} \mathrm{C}, 70{ }^{\circ} \mathrm{C}$ and $76{ }^{\circ} \mathrm{C}$ respectively. Therefore, EVA modified bitumen may be used in the areas of high temperature road carrying heavy traffic.

The effect of EVA modifiers on 80-100 bitumen can be observed in Figure 4. The phase angle decreases with an increase in modifier contents and increases with increase in temperature. The phase angle of neat binder is higher than that of an EVA modified bitumen. This implies that with the EVA modifier, the elastic response of bitumen can be greatly improved. As illustrated in Figure 4, as the phase angle of the base 80-100 bitumen moves towards $90^{\circ} \mathrm{C}$ it will exhibit a more viscous behaviour. The EVA modifier significantly enhances the elastic response of the modified binders. The increase in elastic response at high temperatures can be ascribed to the viscosity of the neat bitumen being sufficiently low to permit the elastic network of the EVA to have an effect on the mechanical properties of the modified binders.

\subsection{Temperature Susceptibility}

The temperature susceptibility, as showed by penetration index (PI), has been calculated for the bitumen as presented in Table 4. The penetration index as shown in Table 4 indicates an enhancement in temperature susceptibility with EVA modification. This result is not surprising because one of the basic aims of using EVA is to improve the temperature susceptibility of bitumen.

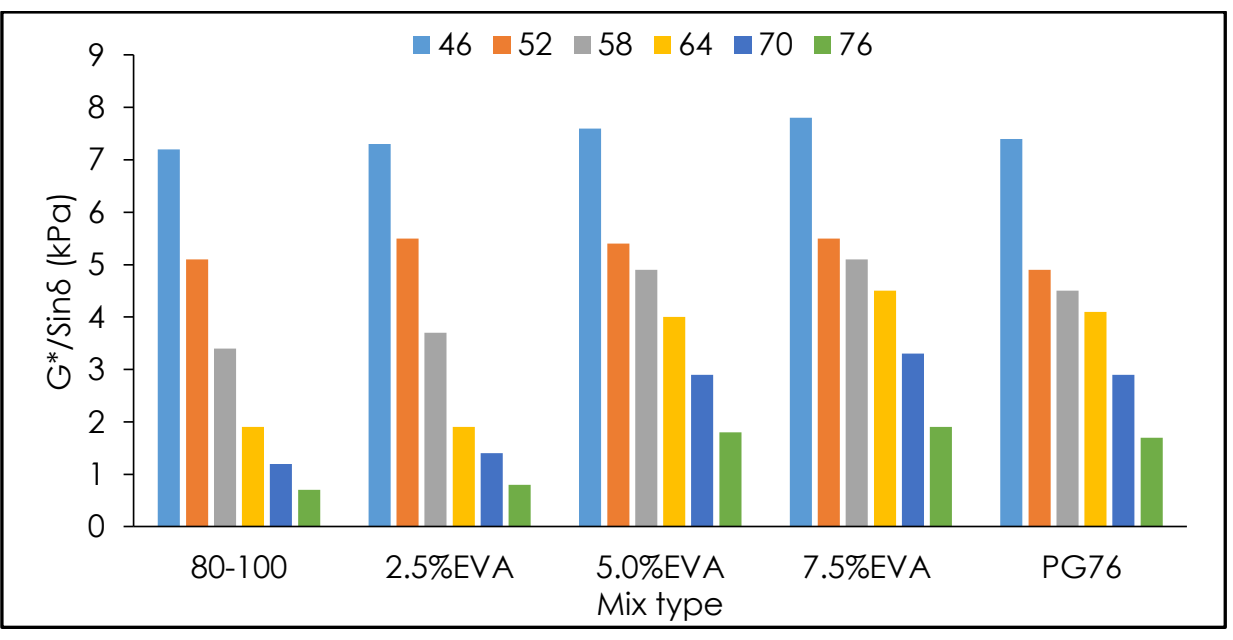

Figure $\mathbf{3}$ The shear modulus results of the bitumen 


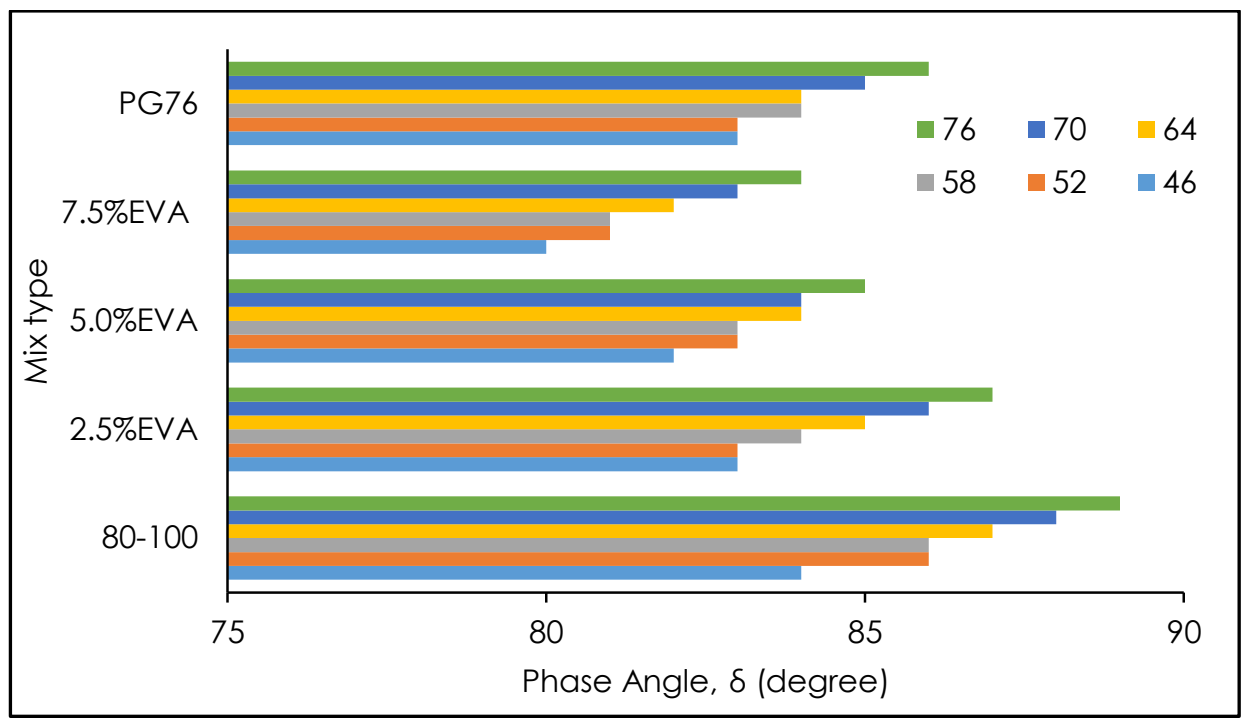

Figure 4 The phase angle results of all bitumen tested

As noticed in Table 4, the $\mathrm{PI}$ increases with the concentration of EVA. PG 76 and 5\% EVA modified 80100 bitumen has identical values of PI. The lowest PI is recorded at $2.5 \%$ EVA. As observed in other properties of the EVA modified bitumen studied in this research, there is a sharp increase in PI at 5\% EVA.
The lower the PI of bitumen, the higher is temperature susceptibility. The $\mathrm{PI}$ is between +1 and -1 for most of the bitumen. Bitumen with a PI below -2 is very liable to transverse cracking in cold climates [28].

Table 4 Summary of the bitumen's properties

\begin{tabular}{|c|c|c|c|c|c|}
\hline Binder type & $\begin{array}{c}\text { Viscosity } \\
\text { at } 135^{\circ} \mathrm{C} \text { (Pa.s) }\end{array}$ & $\begin{array}{c}\mathrm{G}^{*} / \sin \delta \\
\text { at } 76^{\circ} \mathrm{C}(\mathrm{kPa})\end{array}$ & Penetration & $\begin{array}{c}\text { Softening point } \\
\left({ }^{\circ} \mathrm{C}\right)\end{array}$ & $\begin{array}{c}\text { Penetration } \\
\text { Index }\end{array}$ \\
\hline $80-100$ & 0.40 & 0.70 & 85 & 46 & -1.05 \\
\hline $2.5 \%$ EVA $80-100$ & 0.48 & 0.80 & 60 & 56 & 0.67 \\
\hline $5.0 \%$ EVA $80-100$ & 0.63 & 1.79 & 49 & 63 & 1.96 \\
\hline 7.5\% EVA 80 - 100 & 1.20 & 1.89 & 45 & 68 & 2.27 \\
\hline PG 76-22 & 1.80 & 1.70 & 48 & 64 & 1.96 \\
\hline Permissible results & Max. 3 & Min. 1.00 & & & \\
\hline
\end{tabular}

\subsection{Modification Indices}

The modification indices for penetration, softening point and viscosity was determined using equation 1 below:

Modification Index $=\frac{\text { P modified }}{P \text { unmodified }} \times 100$

Where;

$\mathrm{P}$ modified $=$ the same rheological property as measured on the unmodified bitumen, but performed after bitumen modification

$\mathrm{P}$ unmodified = the same rheological property measured on the unmodified bitumen.

Figure 5 shows the modification indices for penetration, softening point and viscosity. The data shown in Figure 5 is not mainly meant to show a relationship between modification index and polymer content but majorly to improve the modification process understanding. As illustrated in Figure 5, although there are variations in the modification index magnitude for the three properties, no specific trend could be identified. While the penetration test seems to be relatively insensitive, the viscosity tests significantly sensitive to the morphology of the EVA and the bitumen binder.

The modification indices for the viscosity and softening point differ from that of penetration. The EVA modified bitumen shows a relatively increase in viscosity and softening point as the EVA content increases from $2.5 \%$ to $7.5 \%$. However, the increase is relatively higher at the $5.0 \%$ polymer level but shows a sharp increase at the $7.5 \%$ level being approximately $77 \%$. Findings have shown that EVA polymer is compatible with most bitumen binders, but in order to 
ascertain the benefits of bitumen polymer modification, a level of incompatibility was necessary $[29,30]$. Excessive degree of compatibility makes the EVA polymer performing simply as a filler in the modified bitumen without reaching a rheological polymer dominant system.

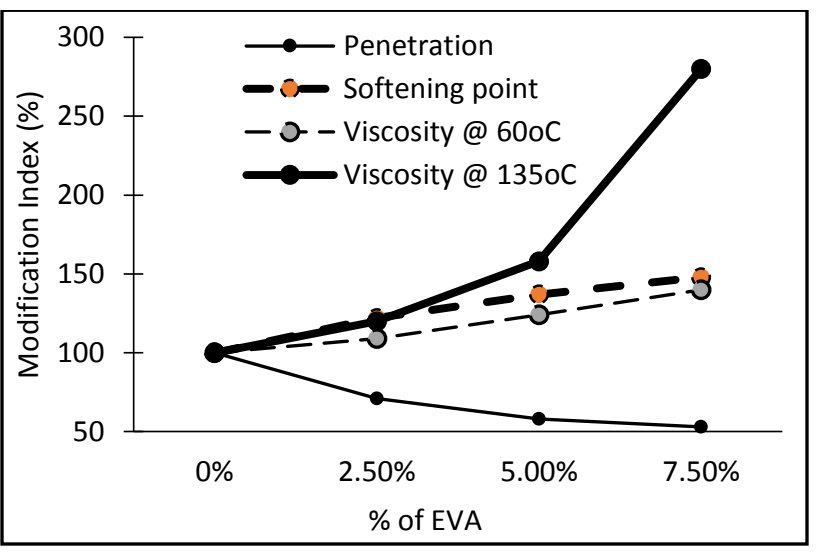

Figure 5 Modification Index

\subsection{CONCLUSION}

Based on the analysis, the penetration and softening points of the neat 80-100 binder are greatly improved with addition of EVA. EVA modified 80-100 bitumen gives lower penetration and higher softening point as compared to neat 80-100 bitumen. As the content of EVA added to the bitumen increases, the more viscous it becomes. The 5\% EVA modified 80-100 bitumen displays characteristic similar to $P G 76$ in terms of penetration and softening point. In term of rheological properties, shear modulus and phase angle of the bitumen are tremendously improved with addition of EVA. By addition of 5\% EVA into 80-100 bitumen, the rutting resistance is significantly increased at $64{ }^{\circ} \mathrm{C}$. Hence, EVA modified 80-100 bitumen can be applied in very high temperature and heavy traffic areas. The study has further confirmed that modification of the bitumen improves the physical and rheological properties of neat bitumen.

\section{Acknowledgement}

Authors would like to thank Universiti Teknologi Malaysia in the form of the Research University Grant (GUP) Tier 1 Vot no. QJ130000.2522.17H96, 11 H35 and Institut Inovasi Strategik Johor (IISJI) Vot no. 15H16.

\section{References}

[1] Bulatovic, V. O., Rek, V. and Markovic, K. J. 2013. Rheological Properties and Stability of Ethylene Vinyl Acetate Polymer - Modified Bitumen. Polymer Engineering and Science. 1-8.
[2] Oluwasola, E. A., Hainin, M. R. and Aziz, M. M. A. 2015. Evaluation of Rutting Potential and Skid Resistance of Hot Mix Asphalt Incorporating Electric Arc Furnace Steel Slag and Copper Mine Tailing. Indian Journal of Engineering and Materials Sciences. 22(5): 550-558.

[3] Abdullah, M. E., Zamhari, K. A., Hainin, M. R., Oluwasola, E. A., Hassan, N. A. and Yusoff, N. I. M. 2016. Engineering Properties of Asphalt Binders Containing Nanoclay and Chemical Warm-Mix Asphalt Additives. Construction and Building Materials. 112: 232-240.

[4] Idham, M. K., Hainin, M. R., Warid, M. N. M., Raman, N. A. A. and Mamat, R. 2015. Evaluation on the Performance of Aged Asphalt Binder and Mixture Under Various Aging Methods. Jurnal Teknologi. 77(23): 7-12.

[5] Aziz, M. M. A., Rahman, M. T., Hainin, M. R. and Bakar, W. A. W. A. 2015. An Overview on Alternative Binders for Flexible Pavement. Construction and Building Materials. 84: 315319.

[6] Abdullah, M. E., Zamhari, K. A., Hainin, M. R., Oluwasola, E. A., Yusoff, N. I. M. and Hassan, N. A. 2016. High Temperature Characteristics of Warm Mix Asphalt Mixtures with Nanoclay and Chemical Warm Mix Asphalt Modified Binders. Journal of Cleaner Production. 122: 326-334.

[7] Hainin, M. R., Matori, M. Y. and Akin, O. E. 2014. Evaluation of Factors Influencing Strength of Foamed Bitumen Stabilised Mix. Jurnal Teknologi. 70(4).

[8] Sufian, Z., Aziz, N. A., Matori, M. Y., Hussain, M. Z., Hainin, M. R. and Oluwasola, E. A. 2014. Influence of Active Filler, Curing Time and Moisture content on the Strength Properties of Emulsion and Foamed Bitumen Stabilized Mix. Jurnal Teknologi. 70(4).

[9] Idham, M. K. and Hainin, M. R. 2015. The Effect of Incorporating Reclaimed Asphalt Pavement on the Performance of Hot Mix Asphalt Mixtures. Jurnal Teknologi. 77(32): 117-123.

[10] Mamat, R., Hainin, M. R., Hassan, N. A., Warid, M. N. M., Raman, N. A. A. and Idham, M. K. 2015. A Review on Performance of Asphalt Mixtures Using Bio Binder as Alternative Binder. Jurnal Teknologi. 77(23): 17-20.

[11] Panda, M. and Mazumdar, M. 1999. Engineering Properties of EVA Modified Bitumen Binder for Paving Mixes. Journal of Materials in Civil Engineering. 11 (2): 131-137.

[12] Yusoff, N. I. M., Mounier, D., Marc-Stéphane, G., Hainin, M. R., Airey, G. D., \& Di Benedetto, H. 2013. Modelling the Rheological Properties of Bituminous Binders using the 2s2pld Model. Construction and Building Materials. 38: 395406.

[13] Airey, G. D. 2002. Rheological Evaluation of Ethylene Vinyl Acetate Polymer Modified Bitumens. Construction and Building Materials. 16(8): 473-487.

[14] Gonzalez, O., Munoz, M. E., Santamarıa, A., GarciaMorales, M., Navarro, F. J. and Partal, P. 2004. Rheology and Stability of Bitumen/EVA Blends. European Polymer Journal. 40(10): 2365-2372.

[15] Morales, M and Partal, P. 2004. Viscous Properties and Microstructure of Recycled EVA Modified Bitumen. Fuel. 83 : 31-38.

[16] Kumar, P., Khan, T. and Singh, M. 2013. Study on EVA Modified Bitumen. Elixir International Journal of Chemical Engineering. 54A: 12616-12618.

[17] American Society for Testing Materials. 2013. ASTM D5M. Standard Test Method for Penetration of Bituminous Materials. Philadephia U.S.: ASTM International.

[18] American Society for Testing Materials. 2012. ASTM D36. Standard Test Method for Softening Point of Bitumen (Ringand - Ball Apparatus). Philadephia U.S.: ASTM International.

[19] American Society for Testing Materials. 2013. ASTM D4402. Standard Test Method for Viscousity Determination of Asphalt at Elevated Temperatures Using a Rotational Viscometer. Philadephia U.S.: ASTM International.

[20] Yusoff, N. I. M., Jakarni, F. M., Nguyen, V. H., Hainin, M. R., \& Airey, G. D. 2013. Modelling the Rheological Properties of Bituminous Binders Using Mathematical Equations. Construction and Building Materials. 40: 174-188. 
[21] Yusoff, N. I. M., Hainin, M. R., \& Airey, G. D. 2012. A Comparative Study of Phase Angle Predictive Equations Using Bituminous Binder Data. Arabian Journal for Science and Engineering. 37(6): 1571-1583.

[22] American Society for Testing Materials. 2008. ASTM D7175. Standard Test Method for Determining the Rheological Properties of Asphalt Using a Dynamic Shear Rheometer. Philadephia U.S.: ASTM International.

[23] McGennis, R. B., Shuler, S. and Bahia, H. U. 1994. Background of Superpave Asphalt Binder Test Methods. FHWA report no. FHWA-SA-94-069.

[24] Read, J, M and Whiteoak, D. 2003. The Shell Bitumen Handbook. Fifth Edition. Thomas Telford Publishing, Thomas Telford Ltd, 1 Heron Quay, London E144JD, 62-66, 136.

[25] Rusbintardjo, G., Hainin, M. R. and Yusoff, N. I. M. 2013. Fundamental and Rheological Properties Oil Palm Fruit Ash Modified Bitumen. Construction and Building Materials. 49: 702-711.
[26] Lavin, P. G. 2003. Asphalt Pavements a Practical Guide to Design, Production and Maintenance for Engineers and Architects. 1st Edition. London: Spon Press. 1-10.

[27] Robert, F. L., Kandhal, P. S., Brown, E. R., Kim, Y. R., Lee, D. Y. and Kennedy, T. W. 2009. Hot Mix Asphalt Materials, Mixture, Design, and Construction. 3rd edition, NAPA Research and Educational Foundation, Lanham, Maryland.

[28] Hussain, M. H. M., Ghaly, N. F. and Ibrahim, I. M. 2008 Modified Hot Mix Asphalt for Road Maintenance. World Applied Sciences Journal. 5(2): 236-245.

[29] Oluwasola, E. A., and Hainin, M. R. 2016. Evaluation of Performance Characteristics of Stone Mastic Asphalt Incorporating Industrial Waste. Journal of Materials in Civil Engineering. 28(12): 06016016.

[30] Oluwasola, E. A., Hainin, M. R., Aziz, M. M. A., and Warid, M. N. M. 2016. Volumetric Properties and Leaching Effect of Asphalt Mixes with Electric Arc Furnace Steel Slag and Copper Mine Tailings. Sains Malaysiana. 45(2): 279-287. 